\title{
MIGRATION OF INFECTIVE LARVAE OF SHEEP GASTROINTESTINAL NEMATODES
}

\author{
Eva HOLASOVȦ, I. PAVLÁSEK, Božena KOTRLÁ
}

Institute of Parasitology, Czechoslovak Academy of Sciences, 37005 Ceské Budéjovice

Received November 11, 1989

\begin{abstract}
H o l a s o vá Eva, I. P a v lá s e k, Božena K o t r lá: Migration of Infective Larvae of Sheep Gastrointestinal Nematodes. Acta vet. Brno, 58, 1989 : 369-378.

The migration of infective larvae of nematodes of the genera Haemonchus, Ostertagia, Trichostrongylus and Chabertia on herbage in the soil was studied under laboratory conditions on three artificially seeded grass plots with different methods of irrigation.

The capacity for vertical migration was found to be the highest, i. e. up to $27 \mathrm{~cm}$, in infective larvae of Trichostrongylus spp. Most of the infective larvae of this nematode were found in the herbage $6-15 \mathrm{~cm}$ above the soil surface. The rate of vertical migration is proportional to the moisture of the herbage. During 3 hours of watering the herbage, infective larvae were found $12-15 \mathrm{~cm}$ above the soil surface, whereas within 4 hours of dessication of the herbage the larvae were concentrated maximally up to $4 \mathrm{~cm}$ from the soil surface.

Infective larvae of $\boldsymbol{H}$. contortus, Trichostrongylus spp. and Chabertia ovina migrated horizontally to a maximal distance of $21 \mathrm{~cm}$ from the middle of the faeces sample established on grass irrigated twice a day.

Infective larvae of the above nematode species occurred only sporadically in soil in the depth of $2 \mathrm{~cm}$; only in one case were infective larvae of Ostertagia spp. found in a depth of $7 \mathrm{~cm}$.
\end{abstract}

\section{Infective larvae, herbage, soil, rate of migration}

From the epizootiological point of view, the infective larvae occurring in the herbage of pastures are one of the most important sources of distribution of helminth invasions.

Several authors have studied the annual occurrence of infective larvae in the external environment, especially on herbage. B ü r g e r et al. (1983) reported that larvae began to migrate from the faeces to the herbage at the time when the average daily air temperature had exceeded $18{ }^{\circ} \mathrm{C}$ for more than a week and after at least 4 days of rainfall when average precipitation was minimally $20 \mathrm{~mm}$. C a $11 \mathrm{i} \mathrm{n}$ a $\mathrm{n}$ and We s t c o t t (1986) stated that the occurrence of larvae on herbage was significantly dependent on the temperature and humidity of the environment.

In the herbage of the studied pastures (in November) in South Australia, $\mathrm{O}$ v e r e $\mathbf{n} \mathbf{d}$ et al. (1984) found as much as 4800 infective larvae per $1 \mathrm{~kg}$ of dry grass. P r o s 1 (1986) studied the quantity of larvae on vegetation during the day and found that the counts of infective 0 . ostertagi larvae were maximum at $6.00 \mathrm{a}$. m. (i. e. $2470 / \mathrm{kg}$ of fresh grass) and minimum in the course of the day (i. e. $390 / \mathrm{kg}$ of fresh grass).

In general, in experiments conducted directly on pastureland, infective larvae migrate horizontally to a distance of $10-12 \mathrm{~cm}$, and vertically $17 \mathrm{~cm}$. F i n c h e r and $\mathrm{S} \mathrm{t} \mathrm{e} \mathrm{w} \mathrm{a} \mathrm{r} \mathrm{t} \mathrm{(1979)}$ reported that $O$. ostertagi larvae in the field migrated vertically at least $12.5 \mathrm{~cm}$, and in glass tubes in the laboratory $15 \mathrm{~cm}$ (from the soil). On the contrary, $\mathrm{Ca} 11 \mathrm{i} \mathrm{n}$ a $\mathrm{n}$ and We s t c o t t (1986) found 71\% of the larvae recovered from the vegetation concentrated within $0-2 \mathrm{~cm}$ of the herbage. P r o s 1 (1986) stated that larvae migrated vertically on the herbage only a few $\mathrm{cm}$ and that during day they descended downwards to the lower grass layer above the soil. D e $1 \mathrm{~g}$ a d o (1983) recovered infective Trichostrongylus and Haemonchus larvae on grass $50-130 \mathrm{~cm}$ above the ground. R o s e (1961) found the infective larvae to migrate more vertically than horizontally. He found the counts of larvae to be the highest in tufts of grass near the faeces. G o l.d b e r g (1970) collected $80 \%$ of $O$. ostertagi, $C$. punctata and $O$. radiatum larvae on grass 
within $13 \mathrm{~cm}$ of the faeces. P r o s 1 (1986) found infective Ostertagia and Cooperia larvae on herbage as much as $40-50 \mathrm{~cm}$ from the faeces, the majority of larvae being collected within $10 \mathrm{~cm}$ of the faeces.

In addition to the migration of larvae in herbage, many authors also investigated the migration of larvae into the soil in connection with their survival during the cold periods and their higher occurrence on herbage during spring and in the dry period. C a 11 o n a $n$ and W e s t c o t t (1986) recovered 8 times more larvae in the soil than on the herbage down to a depth of 4-6 cm. A l S a q u a r et al. (1982) collected soil samples from October till September and found that infective Ostertagia spp. larvae were present in each sample to a depth of at least $15 \mathrm{~cm}$. Analysis of the vertical distribution suggested a possible migration into the soil during winter followed by an upward trend during spring and summer. G r u n e r et al. (1982) observed that towards the end of winter, during two weeks when soil temperature was lower than $6^{\circ} \mathrm{C}$, the larvae migrated to a depth of $40 \mathrm{~cm}$, and more. This migration through the soil was supported by the content of soil water, but the larvae were capable of active migration upwards even under relatively dry conditions. R o s e und S m a 11 (1985) stated that the ability of larvae to migrate into the soil was not even affected by the period of heavy rainfall. The results of studies of these and other authors have proved that infective larvae of many nematodes migrate horizontally over the herbage much more quickly than in the opposite direction - into the soil. These authors concluded that the soil does not serve as a reservoir where large numbers of infective larvae might survive during the winter.

The mechanism of larvae migration in the soil has not yet been fully explained. Based on his experiment with $O$. ostertagi larvae, G r o n v o l d (1979) suggested that in this respect the earthworms might play a certain role; after 50 days he isolated living larvae from their digestive tract and faeces.

The aim of the present study was to find the ability and rate of migration of infective larvae of the most frequently occurring sheep gastrointestinal namatodes on artificially established grassland, and to discuss the presence of infective larvae in soil as a possible reservoir of infective larvae under unfavourable conditions.

\section{Materials and Methods}

Various ways of migration on infective nematode larvae of the genera Haemonchus, Ostertagia, Trichostrongylus and Chabertia were studied. Positive faeces with eggs of the above helminths were collected from spontaneously infected sheep and placed on the experimental plots (see further) under laboratory conditions.

\section{(A) Characteristics of the experimental plots}

The vertical and horizontal migration of infective larvae was investigated in March and April in a greenhouse on three artificially seeded experimental plots $(35 \times 56 \mathrm{~cm})$. The composition of the herbage was as follows: Festuca pratensis, Trifolium repens, Lolium perenne and Dactylis glomerata.

(a) Experimental plot No. 1

Positive faeces were placed on the grass surface into the centre of the plot in the form of a cake $21 \mathrm{~cm}$ in diameter. Before placing the faeces, one half of the plot of grassland was kept at a height of $2 \mathrm{~cm}$ frequent clipping. The herbage on the other half of the plot was $50 \mathrm{~cm}$ high before the beginning of the experiment. The herbage was watered twice a day.

(b) Experimental plot No. 2

The herbage and establishment of faeces were the same as on plot No. 1. Only once a day, the bottom $20 \mathrm{~cm}$ of soil were irrigated by immersing into a large pot with water for 15 minutes.

(c) Experimental plot No. 3

On the third experimental plot the faeces were evenly distributed over the whole surface.

The herbage was not cut and was irrigated twice a day as was experimental plot No. 1; at the time of collection of larvae it reached a height of $50 \mathrm{~cm}$. 
(B) Methods of examinations

Within 35 days of establishment of the faeces samples with the eggs of the above nematode species, the herbage and soil of the experimental plots were divided into squares $7 \times 7 \mathrm{~cm}$. The high herbage was gradually cut into $3 \mathrm{~cm}$ parts, from the soil surface up to the top. Soil samples were taken to a depth of 2 and $7 \mathrm{~cm}$. In pilot field samplings, the soil was taken on the experimental plots in the Ecological Station Klec in April and November to a depth of $20 \mathrm{~cm}$ from $5 \times 5 \mathrm{~cm}$ squares.

All samples were examined for infective nematode larvae of the genera Haemonchus, Ostertagia, Trichostrongylus and Chabertia using the modified method according to Bearmann.

\section{(C) Determination of the rate of migration of the infective larvae}

The rate of migration of the infective larvae in the herbage was ascertained in three $13 \times 13 \mathrm{~cm}$ containers into which the grass mats were set, and the faeces with the infective larvae were over the whole surface. The herbage was continuously watered.

Samples of the herbage were taken gradually from these 8 plots at 15 and 30 min intervals, then at 1 to 6 -hour intervals. The grasss was cut in $2 \mathrm{~cm}$ parts and samples were examined using the modified method according to Baermann. The ability of reverse migration was investigated after dessication using warm air $\left(45^{\circ} \mathrm{C}\right)$.

\section{Results}

\section{Vertical and horizontal migration}

The average air temperature and relative humidity during the whole experimental period from the establishment of the experiment till its termination was $21.3^{\circ} \mathrm{C}$ (from $12^{\circ} \mathrm{C}$ to $28^{\circ} \mathrm{C}$ ) and $74 \%$ (from $52 \%$ to $85 \%$ ), respectively.

(1) Migration of infective larvae on the herbage

The results are given in Fig. 1 and 2 . Fig. 1 shows that on the regularly watered plot the infective larvae migrated horizontally only in the middle part of the experimental plot, maximally $21 \mathrm{~cm}$ from the middle of the faeces sample (part A).

At this distance, infective larvae of Trichostrongylus spp. Chabertia ovina and Haemonchus contortus were recovered. Within $14 \mathrm{~cm}$ of the centre of the plot, infective larvae of Trichostrongylus spp. and Ch.ovina were collected.

As concerns vertical migration of larvae, the figures in the middle of the squares of Fig. 1 give the maximal height (in $\mathrm{cm}$ ) from the soil surface where infective larvae were recovered on the herbage. The present investigations proved that infective larvae of Trichostrongylus spp. had the highest ability of migration. i.e. up to a height of $27 \mathrm{~cm}$. Infective $H$. contortus, Ostertagia spp. and Ch.ovina larvae were found up to a height of $6 \mathrm{~cm}, 15 \mathrm{~cm}$ and $9 \mathrm{~cm}$, respectively, from the faeces. In cut herbage (part B), infective larvae of Trichostrongylus spp. Ostertagia spp. and $\boldsymbol{H}$. contortus were recovered.

Fig. 2 shows the migration of infective larvae on herbage on an unwatered plot with bottom watering. No horizontal migration of infective larvae was observed on this experimental plot and vertical migration occurred only on the high herbage in three squares above the faeces. Examinations of grass samples from these squares showed only the occurrence of infective larvae of Trichostrongylus spp. up to a height of $18 \mathrm{~cm}$.

On the third experimental plot (watered, with regularly distributed faeces), the maximal ability for vertical migration of infective larvae was examined. Infective larvae of Trichostrongylus spp. were found to migrate most frequently up to a maximal height of $27 \mathrm{~cm}$, the majority being collected 6-15 cm above the soil surface. Infective larvae of Ostertagia spp. were recovered from grass samples of $3-9 \mathrm{~cm}$ in height. Infective larvae of $H$. contortus were found in two samples only, i.e. $27-30 \mathrm{~cm}$ and $15-18 \mathrm{~cm}$ above the soil.

(2) Migration of infective larvae in the soil

The results are given in Fig. 3 (plot No.1) and Fig. 4 (plot No.2). Infective larvae of Trichostrongylus spp., Ostertagia spp. and $H$. contortus were recovered from the soil to a depth of $2 \mathrm{~cm}$. Only infective Ostertagia spp. larvae were found in one square in the depth of 


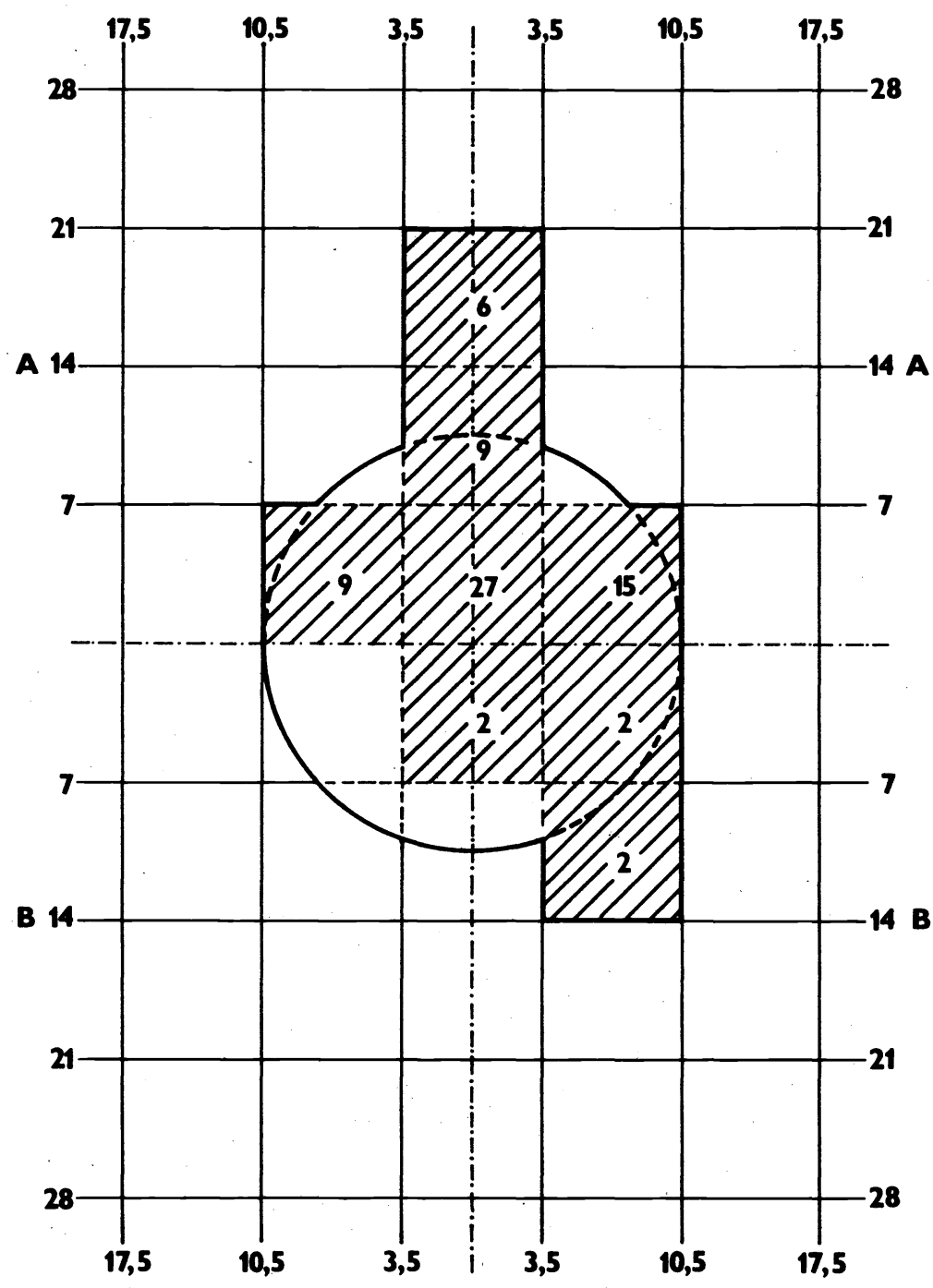

Fig. 1 Results of investigations of infective larvae migration in herbage on experimental plot No. 1

2-7 cm. In pilot field samplings in April, no infective larvae were found in a depth of $20 \mathrm{~cm}$, in November we collected infective Trichostrongylus spp., Ostertagia spp. and H. contortus larvae in a depth of $5-10 \mathrm{~cm}$.

II. Rate of migration

No infective larvae were found on herbage within 15,30 and 60 minutes at $19{ }^{\circ} \mathrm{C}$ and relative air humidity $40 \%$. After 2 hours, infective larvae of Haemonchus contortus, Trichostrongylus spp., Ostertagia spp. and Chabertia ovina were recovered on the herbage up to $8 \mathrm{~cm}$ above the soil; after 3 hours, larvae were found $12-15 \mathrm{~cm}$ above the soil. 
At $22^{\mathrm{C}} \mathrm{C}$ and $45-50 \%$ relative air humidity, infective larvae were found on herbage $2 \mathrm{~cm}$, $6 \mathrm{~cm}$. and $12-15 \mathrm{~cm}$ above the soil within 30 minutes, 1 hour, 2 hours and 3 hours, respectively. The infective larvae of all the species, i. e. Ostertagia spp., Trichostrongylus spp., Haemonchus contortus and Chabertia ovina, were found to migrate.

Reverse migration was also investigated; the herbage with the infective larvae was dessicated with warm air (the temperature above the herbage was $25^{\circ} \mathrm{C}$ and relative air humidity $30 \%$ ) and within 1 hour, 2 hours and 4 hours of dessication infective larvae were found in a height of $10 \mathrm{~cm}, 6 \mathrm{~cm}$ and $4 \mathrm{~cm}$, respectively.

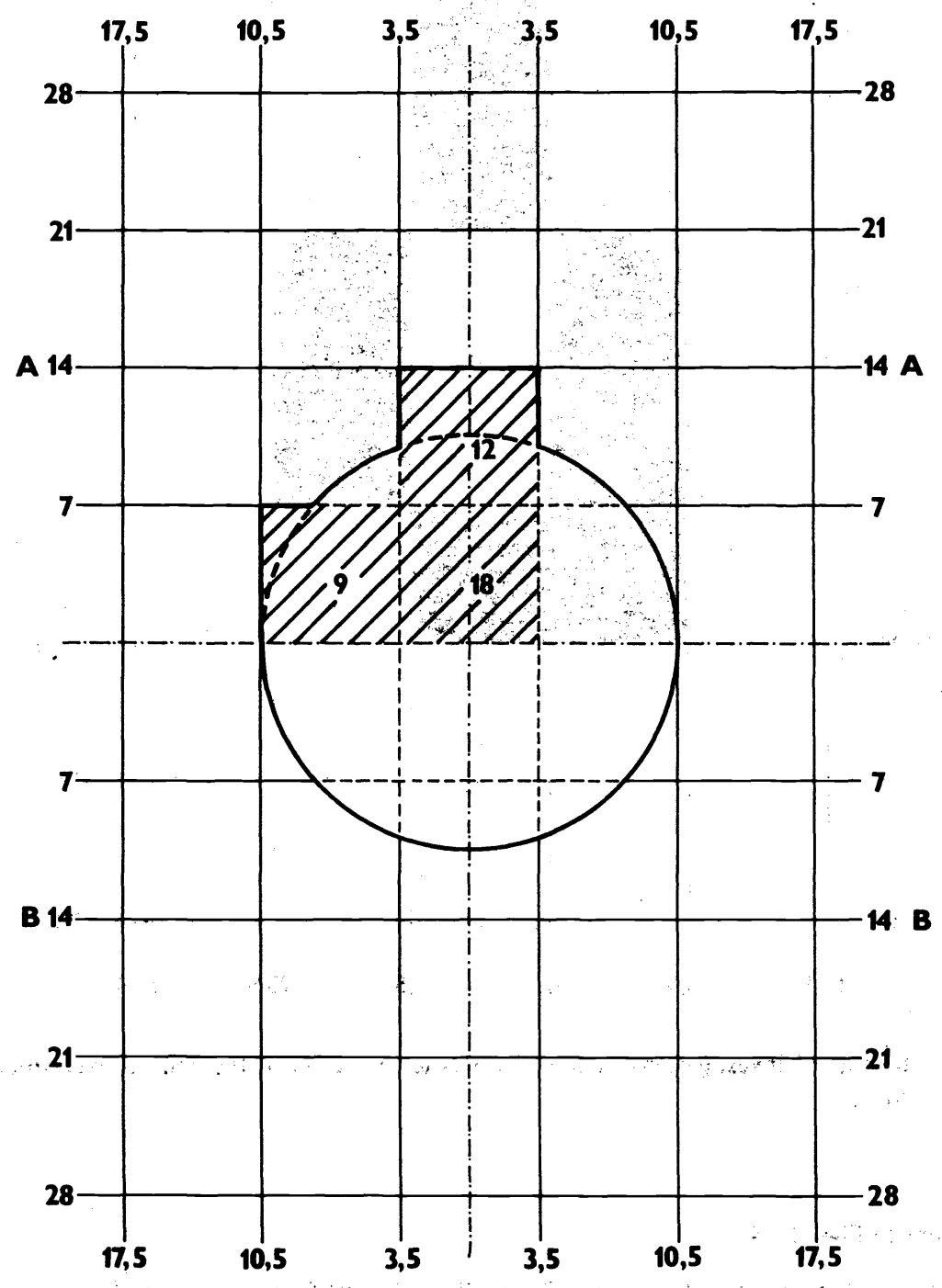

Fig. 2 Results of investigations of infective larvae migration in herbage on experimental plot No. 2 


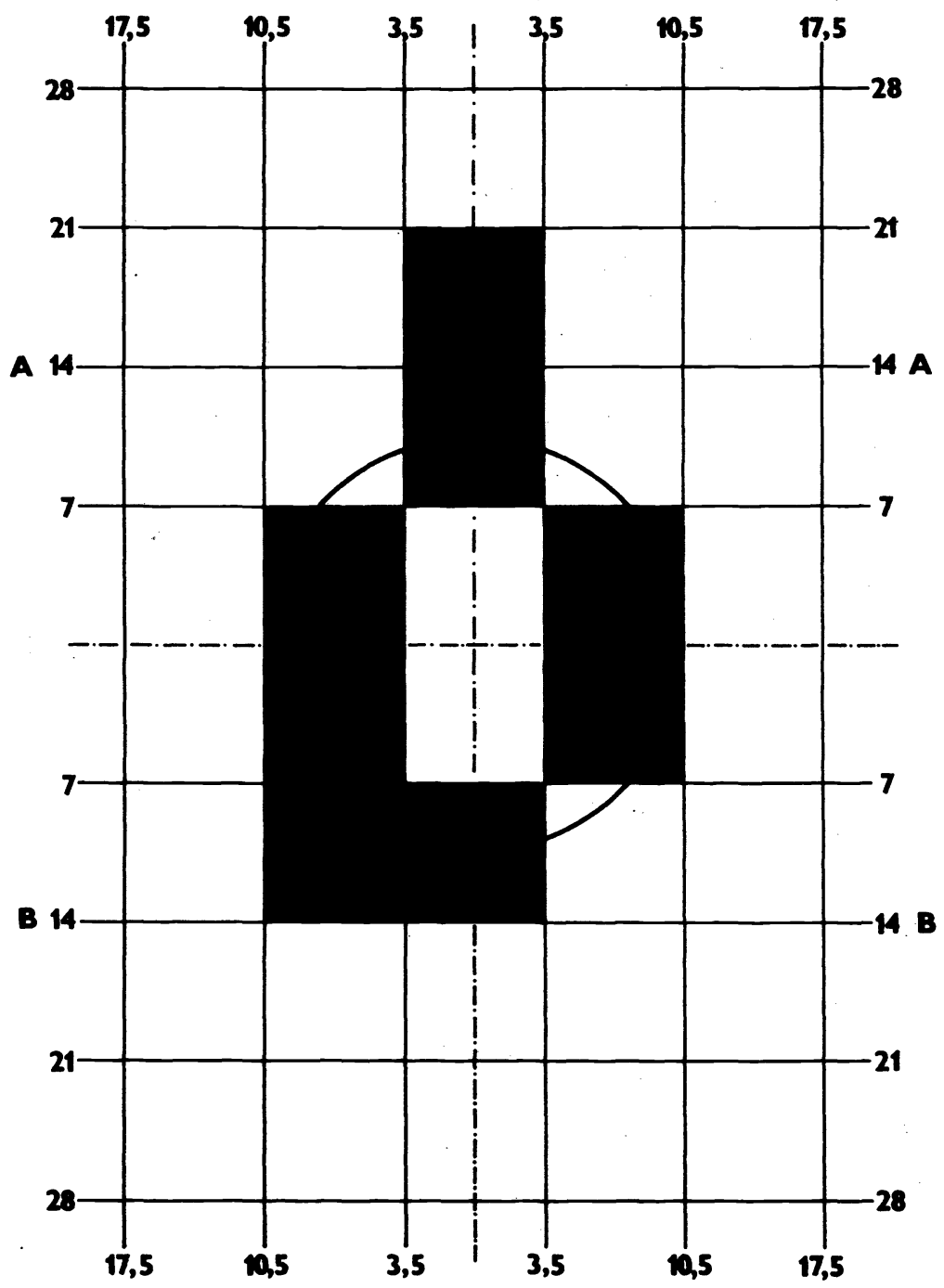

Fig. 3 Results of investigations of infective larve migration in the soil on experimental plot No. 1

Explanstions to Fig. 1-4

Horizontal axis: distance of herbage and soil samplines (in $\mathrm{cm}$ ) from the centre of the experimental plots

Vertical axis: distance of herbage and soil samplines (in $\mathrm{cm}$ ) from the centre of the experimental piots

A - the uncut herbenge 


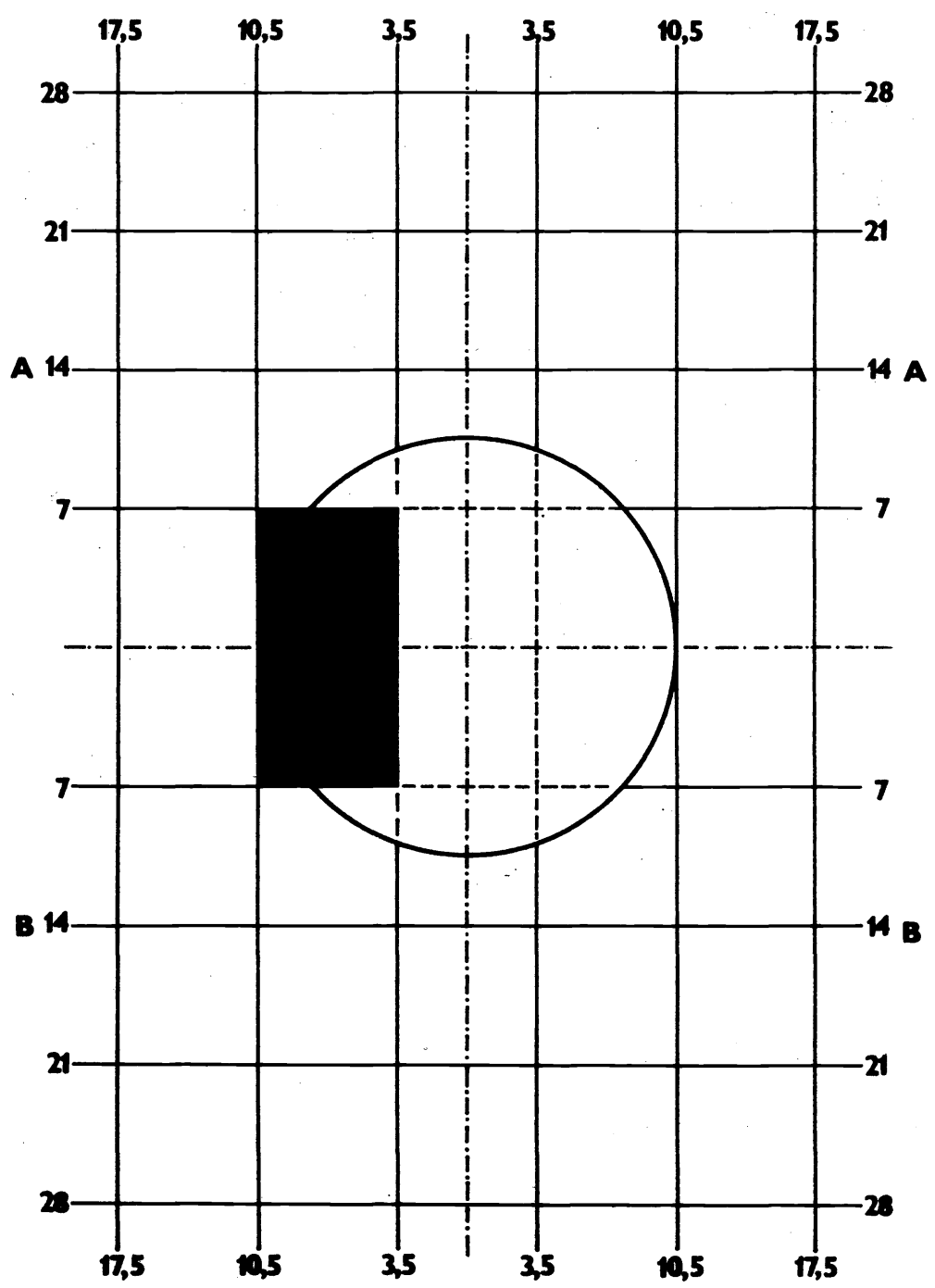

Fie 4 Results of investigations of infective larvae migration in the soil on experimental piot No.2

B - herbage regulerly cut and kept at a maximum height of $2 \mathrm{~cm}$ from the soil surface the circle in the middle of the fiaure indicates the area of estsblished freces sample the crosshatched squares indicate the occurrence of infective larvae in the parts of the grassiand figures in the middle of the crosshatched sections give the maximum height of migration of the infective larve (in cm)

black squares indicate the migration of infective larvee in the soil 


\section{Discussion}

From our observations it is apparent that infective larvae of the genera Haemonchus, Trichostrongylus, Ostertagia and Chabertia migrated vertically, a lesser proportion horizontally. Infective larvae were collected on herbage only above the faeces or in the close vicinity. R o s e (1961) reported that infective larvae migrated more vertically than horizontally and that the largest counts of larvae were recovered from grass tufts near the faeces in the lower layer of the herbage. In their studies, G o 1 d b e r g (1970) and P r o s 1 (1986) described horizontal migration.

In our experiment, the infective larvae of Trichostrongylus spp., at most, migrated vertically, up to a height of $27 \mathrm{~cm}$; the majority of Haemonchus, Trichostrongylus, Ostertagia and Chabertia larvae found at a height of 6-15 cm above the soil with faeces. The results of $\mathrm{F} \mathrm{i} \mathrm{n} \mathrm{ch} \mathrm{e} \mathrm{r}$ and $S \mathrm{t} \mathrm{e}$ w a r t (1979) and D e $1 \mathrm{~g}$ a d o (1983) were similar. On the contrary, C a 11 i n a $\mathrm{n}$ and We s t c ot t (1986) and Pros 1 (1986) collected infective larvae in the lower layers of the herbage.

If the infective larvae are to use their ability for migration, they require humidity which is maintained for a longer time in the dense and high herbage. This fact agrees with the present results when infective larvae on the experimental plot regularly watered, migrated up to a height of $27-30 \mathrm{~cm}$, while they remained in the faeces on the plot with bottom watering.

From the present results it further follows that the migration of infective larvae into the soil is probably not markedly affected either by the permeability or moisture of the soil. Infective larvae of $\boldsymbol{H}$. contortus, Ostertagia spp. and Trichostrongylus spp. were recovered from the soil only sporadically, and only to a depth of $2 \mathrm{~cm}$; only in one case Ostertagia spp. larvae were recovered in a depth of $7 \mathrm{~cm}$. It is true that in orientation field samplings carried out in November, infective larvae were found to reach a depth of $10 \mathrm{~cm}$, but this does not conclusively prove the ability of infective larvae to migrate into the soil, because we cannot exclude contamination during sampling or if the larvae were carried down by percolating water during rainfall. The present results agree with results of $\mathrm{B}$ o r g s t e e d and $\mathrm{B} \circ \mathrm{og}$ a r d (1983), $\mathrm{R} \mathrm{o} \mathrm{s} \mathrm{e}$ and S m a 11 (1985) who recovered very small amounts of infective larvae in the soil. On the other hand, Al S a g u r et al. (1982), G r u ne r et al. (1982) and C a 11 i n a n and We s t c o t t (1986) reported that infective larvae migrated deeply into the soil. The mechanism of larvae migration in the soil has not yet been fully explained; as mentioned above, some authors attach importance to concrete local conditions, others suggest the role of earthworms in the transport of infective larvae in the different layers and depths of the soil.

Observations on the rate of migration have revealed that, under sufficient air humidity and adequate temperature, the infective Haemonchus, Ostertagia, Trichostrongylus and Charbertia larvae are capable of reaching a height of $15 \mathrm{~cm}$ on the herbage within 3 hours. During dessication, the infective larvae migrate downwards again and remain at a height of up to $4 \mathrm{~cm}$ where humidity is sufficient. The onset of migration of the larvae in the herbage is dependent on the temperature and humidity of the environment that is in accordance with the observations of B ü r g e r et al. (1983) and C a 11 i n a n and We s t c o t t (1986).

The ability of infective larvae to migrate quickly in the herbage, including their ability of surviving the relatively very unfavourable environmental conditions, is a very serious epizootiological problem. Ko t r lá and $\mathrm{K}$ o ž d o ñ (1978) observed that not even recurrent winter temperatures connected with hoarfrost decontaminated the pastures. According to these authors, $53 \%$ of the herbage samples on the experimental plot were positive from June till June of the following year. Based on observations of $\mathrm{O} v$ e r e $\mathrm{n} \mathrm{d}$ et al. (1984) and P o s 1 (1986), the pastures are infested with considerable numbers of infective larvae during the whole grazing season. In their studies, $\mathrm{C}$ a b a r e t et al. (1982), $M$ i t c h e 1 and $F$ i t z s i m o $\mathrm{s} \mathrm{s}$ (1983) and $\mathrm{M}$ i t c h e $\mathrm{l}$ et al. (1984) concentrated their attention to testing various types of pastures. They found that systems of so-called „clean pastures“ (i.e. pastures which had not been grazed for 12 months, or pastures ploughed and sown in the autumn and not grazed until the following autumn) did partly reduce the hazard of infesting the grazing animals, especially the young ones, but after a certain period these pastures were infested.

From the present results and from data of other authors quoted in this study, it is apparent that also at the present time the pasture herbage is the main source of distribution of helminthiases; pastures remain to be a very serious epizootiological problem in spite of the fact that the present methods of treating pastures have qualitatively improved as compared with the past. 
Migrace invaznich larev hlístic

gastrointestinálniho traktu ovci

Schopnost migrace invazních larev hlístic rodủ Haemonchus, Ostertagia, Trichostrongylus a Chabertia $\mathrm{v}$ travní porostu a do pủdy byla studována $\mathrm{v}$ laboratorních podmínkách na třech uměle zatravnělých plochách $s$ rüzným režimem zavlažování.

Bylo zjištěno, že největši schopnost vertikální migrace je vyvinuta u invazních larev Trichostrongylus spp., které vystupují až do výše $27 \mathrm{~cm}$. Převážná většina invazních larev výše uvedených hlístic byla nacházena $\mathrm{v}$ travním porostu ve výšce $6-15 \mathrm{~cm}$ od povrchu půdy.

Rychlost vertikálni migrace invazních larev je úměrná vlhkosti travního porostu. Během 3hodinového zavlhčováni travního porostu byly invazni larvy zjištěny ve výšce $12-15 \mathrm{~cm}$, zatímco po 4 hod. vysušování porostu byly larvy soustředěny maximálně do $4 \mathrm{~cm}$ od povrchu pủdy.

Horizontálně migrovaly invazní larvy $H$. contortus, Trichostrongylus spp. a Chabertia ovina $\mathrm{v}$ maximální vzdálenosti $21 \mathrm{~cm}$ od středu založeného vzorku trusu $\mathrm{v}$ podminkách, kdy travní porost byl $2 \times$ denně zavlažován.

Invazní -larvy uvedených druhủ hlístic byly jen ojediněle nalézány $\mathbf{v}$ pủdě do hloubky $2 \mathrm{~cm}$, pouze $\mathrm{v}$ jednom př́padè (invazní larvy Ostertagia spp.) do hloubky. $7 \mathrm{~cm}$.

\section{Миграция инвазионных личинок нематод желудочно-китечного} тракта овец

Способность $\mathrm{k}$ миграции инвазионных личинок нематод рода Haemonchus, Ostertagia, Trichostrongylus и Chabertia в травянистом покрове и в почву изучали в лабораторных условиях на трех искусственно залуженных площадях с разным режимом орошения.

Было установлено, что самая большая -способность вертикальной миграции развита у инвазионных личинок Trichostrongylus spp., продвигающихся на высоту 27 см. Преобладающее большинство инвазионных личинок вышеприведенных нематод находили в травянистом покрове высотой 6-15 см от поверхности почвы.

Скорость вертикальной миграции инвазионных личинок пропорциональна влажности травянистого покрова. В ходе трехчасового орошения травянистого покрова инвазионные личинки были обнаружены на высоте 12-15 см, между тем как после четырехчасового высушивания покрова личинки были сконцентрированы на высоте не более 4 см от поверхности почвы.

Инвазионные личинки $H$. contortus, Trichostrongylus spp. и Chabertia ovina мигрировали горизонтально на максимальное расстояние 21 см от центра образца кала в условиях, когда травянистый покров орошали два раза в сутки.

Инвазионные личинки приведенных видов нематод лишь в единичных случаях находили в почве на глубине 2 см, толко в одном случае (инвазионные личинки Ostertagia spp.) - на глубине 7 см. 


\section{References}

AL SAQUR, I. - BAIRDEN, K - ARMOUR, J. - GETTINBY, G.: Population study of bovine Ostertagia spp. infective larvae on herbage and in soil. Res. Vet. Sci., 32, 1982: 332-337.

BORGSTEEDE, F. H. M. - BOOGAARD, G: Survival of trichostrongylid eggs and larvae in the soil. Tijdshr. Diergeneeskd., 108, 1983: 439-442.

BÜRGER, H. J. - SIEVERS, G. - RATH, C.: Vorhersage der Ansteckungsrisikos für Rinder mit Trichostrongyliden auf Grund won Wetterdaten. Fortschr. Veter. Med. 37: 15, 1983 Kongreßbericht, 301-308.

CABARET, J. - RAYNAUD, J. p. - LE STANG, J. P.: Comparison between tracer calves and herbage samplings for the assessment of pasture infectivity in trichostrongylosis of cattle. Vet. Parasit., 10, 1982: 65-71.

CALLINAN, A. P. L. - WESTCOTT, J. M.: Vertical distribution of Trichostrongylid larvae on herbage and in soil. Inter. J. Parasit, 16, 1986: 241-244.

DELGADO, A. Contribution to the knowledge of the vertical migration of larvae of gastrointestinal strongyles of cattle. Rev. cub. cienc. vet., 14, 1983: 139-146.

FINCHER, G. T. - STEWART, T. B.: Vertical migration by nematode larvae of cattle parasites through soil. Proc. helminth. Soc. Wash., 46, 1979: 43-46.

GOLDBERG, A: Development, migration and survival on pasture of gastrointestinal nematodes of cattle: sumar contamination. Proc. helminth. Soc. Wash., 37, 1970: 166-169.

GRONVOLD, J.: On the possible role of earthworms in the transmission of Ostertagia ostertagi third - stage larvae from feaces to soil. J. Parasit., 65, 1979: 831-832.

GRUNER, L. - MAULEON, H. - SAUVE, CH.: Migrations of trichostrongyle infective larvae experiments with ovine parasites in soil. Ann. Rech. Vét., 13, 1982: 51-59.

HULfNSKÁ, I.: Die Determinationsmerkmale der Invasionslarven bei Schaftarmhelminthen. Acta. Sc. Nat. Brno, 3, 1969: 1-35.

KOTRLÁ, B. - KOŽDOÑ, O.: Pastviny jako zdroj helmintóz ovcí a skotu. Vet. med., Praha, 23, 1978: 39-48.

MITCHELL, G. B. B. - FITZSIMONS, J.: Control of ovine gastrointestinal helminthiasis by the use of "clean" grazing and strategic dosing in the field. Res. Vet. Sci., 35, 1983: 100-105.

MITCHELL, G. B. B. - Fitzsimons, J. Mathieson, A. O.: Comparative study of gastrointestinal helminthiasis in sheep on "clean ${ }^{*}$ grazing and permanent pasture under field conditions. Rev. Vet. Sci., 36, 1984: 364-369.

OVEREND, D. - VEALE, P. I. - COPLAND, J. W.: An epidemiological study of trichostrongylidiasis in dairy cattle grazing irrigated pastures. Austr. Vet. J., 61, 1984: 169-174.

PROSL, H.: Zur Epidemiologie der Trichostrongylidose der Rinder auf Osterreichischen Almweiden. Wien, tierärztl. Mschr. 73, 1986: 338-358.

ROSE, J. H.: Some observations on the free-livin stares of Ostertagia ostertagi, a stomach worm of cattle. Parasitol., 51, 1961: 295-307.

ROSE, J. H. - SMAL, A J.: The distribution of the infective larvae of sheep gastro-intestinal nematodes in soil and on herbere and the vertical miaration of Trichostrongylus vitrinus larvae throunh the soil. J. Fidminth, 5, 1935: 127-135. 